\title{
THE GRADUAL CURTAILMENT OF THE ROYAL PREROGATIVE
}

\author{
Noel Cox
}

\section{INTRODUCTION}

In the United Kingdom and those countries that recognise Elizabeth II as their Queen, ${ }^{1}$ there are to be found certain fundamental constitutional principles. One of these is that much of the legal basis of executive power derives from the Crown, ${ }^{2}$ though this has, in the past, often been downplayed for political and other reasons. Indeed, in the Commonwealth as a whole, political independence has often been equated with the reduction of the role of the Crown to a position of subservience to the political executive. ${ }^{3}$ What remains important is the position of the Crown as an organising principle of government (the framework upon which the structure of government is built ${ }^{4}$ ), as a source of legitimacy, and as a symbol for permanent government. Executive power, therefore, remains based on the royal prerogative, and the 'third source' of authority (the legal powers of the legal natural person, as the Crown is a corporation aggregate), as well as upon statute law.

The royal prerogative is the residue of royal power which derives from the ancient rights, privileges and powers of the Sovereign, including the prerogative of mercy, political prerogatives such as declaring war or peace, and financial prerogatives such as bona vacantia. Within the scope of the

\footnotetext{
*Aberystwyth University.

${ }^{1}$ These countries include Antigua and Barbuda, Australia, the Bahamas, Barbados, Belize, Canada, Grenada, Jamaica, New Zealand, Papua New Guinea, Saint Kitts and Nevis, Saint Lucia, Saint Vincent and the Grenadines, the Solomon Islands, Tuvalu, and the United Kingdom.

2 B V Harris "The 'Third Source' of Authority for Government Action" (1992) 108 Law Quarterly Review 626. For a definition of the Crown, see Janine Hayward "In Search of a Treaty Partner: Who, or What, is "The Crown?"' (1995) Victoria University of Wellington $\mathrm{PhD}$ thesis.

${ }^{3}$ David E Smith "Bagehot, the Crown, and the Canadian Constitution" (1995) 28 Canadian Journal of Political Science 623-624.

${ }^{4}$ Recent examples include Crown Health Enterprises.
} 
royal prerogative, the Sovereign once had a comparatively free hand to act. ${ }^{5}$ Yet even these powers are now limited by the legal concept of convention, ${ }^{6}$ and, more recently, by the principles of administrative law. ${ }^{7}$ The Sovereign enjoys certain powers, but these are to be exercised (for the most part) by Ministers responsible to Parliament, rather than by the Sovereign personally, without, however, prior authorisation - or subsequent validation - by Parliament.

The idea that the prerogative is an uncomfortable fit with the supremacy of Parliament, and the rule of law, ${ }^{8}$ weakens its position (as does other factors), for it was seen as something of an enigma, or even a black hole. The very survival of the prerogative is now questioned in some quarters, though whether the curtailment of the prerogative results in its eventual extinction is a moot question - as is the question of whether this would be a desirable outcome.

\section{CURTAILMENT OF THE PREROGATIVE}

Lord Cooke of Thorndon, in writing on the place and nature of the Crown, has built upon the views of Sir Owen Dixon, who saw the evolution of constitutional law, both in the United Kingdom, and in the overseas realms of the Crown, as the product of the interplay between three potentially conflicting conceptions. These were the supremacy of the law, the supremacy of the Crown, and the supremacy of Parliament. ${ }^{9}$ This interplay has produced the present constitutional structure, whose defining aspects are identified,

\footnotetext{
${ }^{5}$ The seventeenth century view was that the courts would not enquire into the manner of use of an admitted prerogative - at any rate if the holder was not shown to be acting in bad faith; Darnel's Case ("the Case of the Five Knights") (1627) 3 State $\operatorname{Tr}$ 1; reaffirmed by Chandler v Director of Public Prosecutions [1962] 3 WLR 694.

${ }^{6}$ Conventions are similar to legal rules, but they cannot be enforced by the courts; Madzimbamuto v Lardner-Burke [1969] 1 AC 645 (PC); NO 1968 (2) SA 284; Adesebenro $v$ Akintola [1963] AC 614, 630. They are rules of political practice which are regarded as binding by those to whom they apply. Laws are enforceable by the courts, conventions are not; Colin Munro "Laws and Conventions Distinguished" (1975) 91 Law Quarterly Review 218.

${ }^{7}$ See the Operation Dismantle Case (1985) 18 DLR ( $\left.4^{\text {th }}\right) 481$ (SCC); (1983) 3 D.L.R. $\left(4^{\text {th }}\right) 193$ (FCA); Clive Walker "Review of the Prerogative" (1987) Public Law 62.

${ }^{8}$ Thomas Poole "United Kingdom: The Royal Prerogative" (2010) 8(1) ICON 146155 at 147.

9 "The Law and the Constitution" (1935) 51 Law Quarterly Review 590; Lord Cooke of Thorndon "The Suggested Revolution Against the Crown" in Philip Joseph Essays on the Constitution (1995) pp 28-40.
} 
though perhaps misunderstood, by Montesquieu. ${ }^{10}$ This is the origin and antecedent of both the rule of law and the separation of powers.

The supremacy of the law is an idea that we owe to the early Middle Ages. ${ }^{11}$ There was then no concept of the sovereign state, at least in part because everyone had a different lord to whom they owed allegiance. ${ }^{12}$ To many in the seventeenth century the law was the true sovereign. With the Reformation a true theory of sovereignty became possible, because of the vast increase in the powers and activity of the legislature. Judges, as professors of the common law, claimed for it supreme authority. Had this been admitted they would have been the ultimate authority in the state, ${ }^{13}$ as perhaps they are today in the United States of America, where the separation of powers, and an entrenched constitution, ensure a major constitutional role for the judiciary.

Oresme argues that legislative power is vested in the people as a whole, since they alone can judge the common good. ${ }^{14}$ This view was roughly compatible with the English constitutional position in the latter Middle Ages, when Parliament was regarded as the indispensable forum for the production of statute law. ${ }^{15}$ Fortescue arrived at a similar conclusion, though by a very different route. This was a result of his experience in the English law courts, where he concluded that:

"The statutes of England ... are made, not only by the Prince's will, but also by the assent of whole realm, so they cannot be injurious to the people nor fail to secure their advantage."16

${ }^{10}$ Charles de Secondat Baron de Montesquieu "The Spirit of the Laws" in A Lijphart, (ed) Parliamentary versus Presidential Government (1992), 48-51.

${ }^{11}$ In England, Reginald Pecock and John Fortescue, and on the Continent, Pierre D’Ailly, Nicholas of Cusa; Reginald Pecock Donet (1921) p 76; Sir John Fortescue In Praise of the Laws of England (De Laudibus Legum Anglia) S B Chrimes (ed) (1942), c 36 p 87; Sir Robert Carlyle and AJ Carlyle A History of Mediaeval Political Theory in the West (1903-36), vol VI pp 138 and p 141.

${ }^{12}$ Frederic Maitland and Sir Frederick Pollock History of English Law Before the Times of Edward I ( $2^{\text {nd }}$ edn 1895), vol 1 p 182.

${ }^{13}$ J N Figgis The Theory of the Divine Right of Kings (1914) p 230.

${ }^{14}$ Nicole Oresme Le Livres de Politiques d'Aristotle A D Menut (ed) (1970) Transactions of the American Philosophical Society 137-138.

${ }^{15} \mathrm{He}$ followed Masilius drawing on Roman law and Aristotelian utility; Jean Dunbabin "Government" in J H Burns The Cambridge History of Medieval Political Thought c350-c1450 (1988) 507.

${ }^{16}$ Sed non sic Angliae statuta oriri possunt, dum nedum principis voluntate sed et totius regni assensu ipsa conduntur, quo populi laesuram illam efficere requeunt vel non corum commodum procurare. 


\section{THE GRADUAL CURTAILMENT OF THE ROYAL PREROGATIVE}

Fortescue's doctrine of English kingship was that it was dominium politicum et regale, in contrast with the French dominium regale. ${ }^{17}$

Continental princes ruled on the basis of the civil law of their stronger Roman heritage. ${ }^{18}$ They relied especially on the maxim quod principi placuit legis habet vigorem. ${ }^{19}$ English kingship was superior, at least, according to the chancellor in Fortescue's fictitious disputation which comprises the basis of De Laudibus Legum Anglia, because the monarchy was limited by the requirement for the assent of Parliament. This was despite the fact that the power of kings was everywhere the same, but authority differed because of differences in their origins. The laws of England were more venerable, and must be deemed to be the best obtainable. This was because they were not enacted at the sole behest of the prince, but by the prudence of 300 members of Parliament. ${ }^{20}$

The Reformation Parliament settled the conventional view of the English constitution so clearly expounded in Sir Thomas Smith's De Republica Anglorum (1565) and so hard to find even obscurely stated before $1530 \mathrm{~s} .{ }^{21}$ As a result of the Reformation, the doctrine of parliamentary supremacy was developed. ${ }^{22}$ But a long fight was waged by King Charles I in defence of his prerogative. He was committed to the traditional symbiosis of royal prerogative and law rather than any new theory of the state. ${ }^{23}$

In the course of time the King-in-Parliament, the legislature, became supreme over the law. On the Continent the lawyers were antagonistic to representative assemblies, and there courts persisted in maintaining the predominance of the law over the authority of such assemblies, and so

- Sir John Fortescue In Praise of the Laws of England (De Laudibus Legum Anglice) ed S B Chrimes (1942), 41.

${ }^{17}$ A limited monarchy, in contrast to an absolute monarchy; Sir John Fortescue The Governance of England notes by Charles Plummer (1979).

${ }^{18}$ The extent to which the common law resisted the reception of Roman law has been much disputed, though recent research suggests that the mediæval common law, though surviving in an organic sense, actually underwent a substantial reformation in the Renaissance period, especially 1490s to 1540s; See the introduction to The Reports of Sir John Spelman (1978), vol II Seldon Society vol 94; Sir John Baker "English Law and the Renaissance" (1985) Cambridge Law Journal 46.

19 "What hath pleased the prince has the force of law".

${ }^{20}$ Sir John Fortescue In Praise of the Laws of England (De Laudibus Legum Anglice) ed SB Chrimes (1942) pp xii-xcviii.

${ }^{21}$ Sir Thomas Smith was a civil lawyer who stood analytically outside the constraints of the common law tradition.

${ }^{22}$ Sir Geoffrey Elton Reform and Reformation, 1509-1558 (1979) pp 199-200.

${ }^{23}$ Kevin Sharpe The Personal Rule of Charles I (1992) p 930. 
encouraged the growth of absolutism. In England after 1688 no claim was made that any rule of the common law was too fundamental to admit of change. The course of our constitutional and legal development must have been profoundly different had it been otherwise. ${ }^{24}$ It is unclear just when parliamentary sovereignty triumphed over the supremacy of the Crown, but Parliament took control of the succession in 1689 , and asserted it in $1701 .^{25}$ The law remained supreme over all organs of government as well as people, and legislative power (properly expressed) extended over the whole field of law. ${ }^{26}$

The growth of the territorial state brought about the need for one supreme authority. As a consequence came a more modern doctrine, a doctrine embodying a conception that was widely held. This was the supremacy of the Crown as the mystical holder of the sovereignty of the state. Continental Europe found in kingship the state's source of unity and power. This was to remain the lynch-pin of constitutional theory until modern times.

The majesty of the Holy Roman Emperor had spread all over Europe in the thirteenth century. To this doctrine of the divine right of kings, habits of thought of the greatest consequences have been traced. These include a deep sense of the majesty of the law, and the duty of obedience. ${ }^{27}$ When the competing focal points of sovereignty were reconciled in the course of the seventeenth and eighteenth centuries, the splendour of the Crown remained as the legal expression of the sovereignty of the nation. The supremacy of the Crown necessarily had to give way under the inexorable advance of the supremacy of Parliament - but need not necessarily disappear altogether.

The aims of the late mediæval and early modern State were negative and disciplinary. The extreme emphasis on property rights carried with it an emphasis on law - a lawyer's rather than a politicians view of government. By Fortescue's time if not earlier, men felt strong monarchy upheld their rights (a mass of technical rules and practices), rather than Parliament. ${ }^{28}$

\footnotetext{
${ }^{24}$ Owen Dixon "The Law and the Constitution" (1935) 51 Law Quarterly Review 590 .

${ }^{25}$ See, for example, H T Dickinson "The Eighteenth-Century Debate on the 'Glorious Revolution"” (1976) 61 History 28-45; H T Dickinson "The Eighteenth-Century Debate on the Sovereignty of Parliament" (1976) 26 Transactions of the Royal Historical Society ( $5^{\text {th }}$ Series) pp 189-210.

${ }^{26}$ I R Christie Wars and Revolutions (1982) p 21.

27 J N Figgis The theory of the Divine Right of Kings (1914) p 266.

${ }^{28} \mathrm{~J}$ R Lander The Limitations of English Monarchy in the Later Middle Ages (1989) pp 4-6.
} 


\section{THE GRADUAL CURTAILMENT OF THE ROYAL PREROGATIVE}

De Laudibus Legum Angliae, ${ }^{29}$ written 1468-71, was one of the first coherent exercises in comparative law. It was strongly influenced by the French experience of Sir John Fortescue. It had a direct influence on the constitutional thinkers of the seventeenth century. Fortescue's successors in that century argued more precisely that the ancient constitution was AngloSaxon - and the royal prerogative was the right of conquest of William the Conqueror. ${ }^{30}$ Fortescue supports the doctrine of constitutional monarchy found in St Thomas, but really his support is derived from his own liberal sentiments and the experience of England. ${ }^{31}$

The contention, most clearly expressed by Aquinas, that the King was not restrained by law because he controlled coercion, was widely rejected in thirteenth century England. Royal jurisdiction depended on co-operation. ${ }^{32}$ In both England and France Giles of Rome's view that "laws are laid down by the prince and established by princely authority", ${ }^{33}$ was disputed. ${ }^{34}$ Bracton regarded the magnates as having an essential role in legislation. ${ }^{35}$

Since 1688 Whigs had insisted that the Sovereign was the servant rather than the master of the people, even though the legal forms implied rather more than this. But this still left the extent of the active role of the Sovereign undecided. For most of the nineteenth century the Whigs assumed a "constitutional monarchy" should keep clear of the everyday turmoil of party politics (as Bagehot would have it), and this ultimately became, in the twentieth century, the official orthodoxy.

\footnotetext{
${ }^{29}$ Sir John Fortescue In Praise of the laws of England (De Laudibus Legum Anglia) ed SB Chrimes (1942).

${ }^{30}$ Robert Brady argued that Parliament and the common law were not part of an ancient and immemorial constitution, but traceable instead to the Conquest and the institution of feudalism; J G A Pocock The Ancient Constitution and the Feudal Law; A Study of English Historical Thought in the Seventeenth Century (2 ${ }^{\text {nd }}$ edn, 1987), chap 8; Sir James Holt Magna Carta and Mediaeval Government (1985) pp 3-8.

${ }^{31}$ Sir John Fortescue The Governance of England notes by Charles Plummer (1979) p 172 .

32 Jean Dunbabin "Government" in J H Burns The Cambridge History of Medieval Political Thought c350-c1450 (1988) pp 505-506.

${ }^{33}$ Giles of Rome De regimine principum (Rome, 1556), I, ii, 10, 1556 fol 44v

${ }^{34}$ Aquinas in particular was not convinced by the Latin tag; St Thomas Aquinas, J Gilbey et al (eds) (1964-80), I, IIae, qu 90, art 3.

${ }^{35}$ Henry de Bracton On the Laws and Customs of England ("Henri de Bracton de Legibus et Constuetudinibus Angliae") G E Woodbine (ed); trans SE Thorne (1968), vol. II, p 21.
} 
By early in the nineteenth century analytical jurists had made parliamentary sovereignty the pivot of the legal system. ${ }^{36}$ The constitution depended upon the common law, whose creature it was. The legal expression of the power of the state was always through the Crown. But there is nothing which transcends the power of an Act of Parliament. ${ }^{37}$ Parliament's power to suspend the law is absolute. But this position was reached comparatively recently, and is not necessarily immutable. The law alone remains permanent and ever-present, in a way similar to the later conceptualisation of the Crown.

It was agreed after 1815 that a Sovereign should be kept out of party politics. ${ }^{38}$ Over the course of the nineteenth century the monarchy moved from sharing government, to having a share in government, to a largely advisory role, ${ }^{39}$ and in the later years of the reign of Victoria the growing importance of organised political parties gave her less room to manoeuvre than her predecessors. ${ }^{40}$ Responsible government prevailed, but the source for executive power remained the royal prerogative, whose basis was the law, not parliamentary sanction.

Since then belief in the supremacy, or sovereignty of Parliament has prevailed. But the ancient balance of the constitution depended not merely upon democracy. It rested - and today still rests in all those countries with a Westminster system of parliamentary democracy and the separation of powers imbrued with the principle of the rule of law - upon the supremacy of the Crown-in-Parliament, and the survival of a legitimacy which extends well beyond mere majoritarian representative democracy.

The value of the royal prerogative is that it can be exercised free of parliamentary control; conversely this is what Harris sees as a weakness and would bring to an end. There is no clear argument, however, as to why majoritarian representative democracy, operating through Members of Parliament, should necessarily provide a greater mandate for executive government action than the legitimacy derived from the ancient prerogatives of the Crown. Curiously, Harris writes of the "expected role of Parliament as

\footnotetext{
${ }^{36}$ See William Hearn The Government of England: Its Structure and its Development (1867), which was a major influence on Dicey.

${ }^{37}$ Owen Dixon "The Law and the Constitution" (1935) 51 Law Quarterly Review 593-595. Nor will the courts be eager to question the authority of an Act of Parliament, a principle cited as early as 1455; P 33 Hen VI 17, 8 at 18 per Fortescue, CJKB.

38 H J Hanham The Nineteenth Century Constitution, 1815-1914 (1969), 30.

${ }^{39}$ John Cannon and Ralph Griffiths The Oxford Illustrated History of the British Monarchy (1988) p 530.

${ }^{40}$ H J Hanham The Nineteenth Century Constitution 1815-1914 (1969) p 25.
} 


\section{THE GRADUAL CURTAILMENT OF THE ROYAL PREROGATIVE}

the sole authoriser of executive action". ${ }^{41}$ The democratic mandate is important in the legislative process; but it is less clear that it should be exercised through Parliament, when we are considering actions of the executive. After all, the executive is already totally dependent upon parliamentary support, through the principle of ministerial responsibility, and the need for parliamentary supply.

The scope of the royal prerogative has not gone uncontested - indeed its history is one of challenge, especially in the seventeenth century. ${ }^{42}$ There has been some discussion recently of curtailing or even abolishing, the royal prerogative, in the United Kingdom, ${ }^{43}$ in New Zealand, and elsewhere. Though it would be incorrect to In the United Kingdom this call has been particularly associated with the deployment of troops to foreign theatres of war, ${ }^{44}$ though it can scarcely be called a 'groundswell' of public opinion demanding comprehensive replacement of the royal prerogative, as Harris could be inferred to suggest is the case. ${ }^{45}$ After initially announcing plans for a sweeping reform of the prerogative the Government has decided to undertake only a small amount of tidying up work. ${ }^{46} \mathrm{~A}$ draft Constitutional Reform and Governance Bill was published in the United Kingdom in March 2008, containing provisions for the statutory replacement of a modest

${ }^{41}$ B V Harris "Replacement of the Royal Prerogative in New Zealand" (2009) 23 New Zealand Universities Law Review 285 at 298.

${ }^{42}$ The insistence, in the Militia Ordinance of March 1642, that control of the militia should be vested in Parliament - a direct assault on the prerogative - was justified entirely in neo-Roman terms; Adam Tomkins Our republican constitution (2005), 89; Quentin Skinner, "Classical Liberty Renaissance Translation and the English Civil War" in Visions of Politics (2002), 326 (see Cicero's maxim that salus populi suprema lex est ["the safety of the people is the supreme law"]).

${ }^{43}$ The Labour Government is committed to moving progressively towards replacement of the major remaining royal prerogative powers with statutory authority. See The Governance of Britain (July 2007) Cm 7170, and The Governance of Britain - War Powers and Treaties: Living Executive Powers (October 2007) CP 26/07. The Conservative Party and the Liberal Democratic Party also favour some reforms: David Cameron "Modernisation with a Purpose" speech launching the Democracy Task Force, $6^{\text {th }}$ February 2006; For the People, By the People (2007) Policy Paper No 83, paras 5.8-5.8.3.

${ }^{44}$ Particularly, according to Harris, the Falkland Islands, Kuwait, Bosnia and Afghanistan; B V Harris "Replacement of the Royal Prerogative in New Zealand" (2009) 23 New Zealand Universities Law Review 285-314.

${ }^{45}$ Ibid, at 287.

${ }^{46}$ The Governance of Britain (July 2007) Cm 7170; Ministry of Justice, "Review of the Executive Royal Prerogative: Final Report" (Ministry of Justice, London, $15^{\text {th }}$ October 2009). 
selection of royal prerogative powers. ${ }^{47}$ Other steps may follow in the United Kingdom.

Harris, in a recent article, argues for the eventual replacement of surviving royal prerogatives in New Zealand with statutory authority. ${ }^{48}$ His thesis for this is comparatively simple. The common law royal prerogative, statute law, and the so-called 'third source' of authority, are the legal bases for executive action. ${ }^{49}$ However, the royal prerogative doesn't meet the standard of an ideal model (which he proposes); it is less democratic, less certain, less accessible, and less easily understood. This argument, however, involves a paradox; the royal prerogative "as currently perceived" falls short of the ideal model; but the model itself is a conceptual construct which itself can be subject to criticism.

While a more deliberate conceptual design approach to the provision of legal authority for executive action may well be desirable, it has not been established that this necessitates a statutory basis (or indeed another basis) for authority replacing the royal prerogative. It is true that there may be no consistent source for executive powers (though there are only three sources ${ }^{50}$ ), but it is not clear why that should lead to support for the triumph of parliamentary supremacy over the supremacy of the law (or indeed of the Crown). In the event of the adoption of an entrenched written constitution, in either New Zealand or the United Kingdom, the matter might well be different, for in that case the source of all authority could ultimately be the constitution itself, though it would not necessarily be so - in Australia the source is the people, despite what the Constitution appears to say. ${ }^{51}$

47 The Governance of Britain - Draft Constitutional Renewal Bill (March 2008), Cm 7342-11, and the Report of the Joint Committee of the House of Lords and House of Commons on the Draft Constitutional Renewal Bill (31 ${ }^{\text {st }}$ July 2008), HL Paper 166-I HC Paper 551-I.

48 B V Harris "Replacement of the Royal Prerogative in New Zealand" (2009) 23 New Zealand Universities Law Review 285. A few years earlier, in "The Constitutional Future of New Zealand" (2004) New Zealand Law Review 269 at 308, Harris speculated that if New Zealand were to adopt a written constitution it could provide for the royal prerogative "to survive, and be relevant to the new institutions of government created under the written constitution".

49 B V Harris "The 'Third Source' of Authority for Government Action" (1992) 108 Law Quarterly Review 626; BV Harris "The 'Third Source' of Authority for Government Action Revisited” (2007) 123 Law Quarterly Review 225.

${ }^{50}$ Ibid.

51 Australian Capital Television Pty Ltd v Commonwealth (1992) 177 CLR 106, 138 per Mason CJ. 


\section{THE GRADUAL CURTAILMENT OF THE ROYAL PREROGATIVE}

To overly promote and emphasise one branch of government over the other is weakening of the separation of powers, for this is not the legislature asserting its law-making role; it is the legislature infringing on the role of the executive to make and implement policy. Thus, to address one perceived weakness in the system in this manner is actually creating a new imbalance. The very independence of the royal prerogative from parliamentary control is arguably its strength, not a weakness.

The royal prerogative may not be based on parliamentary mandate, prior or subsequent, but that does not mean that it lacks its own legitimacy. Blackstone himself observed that one of the strengths of the prerogative:

"was the limitation of the king's prerogative by bounds so certain and notorious, that it is impossible he should ever exceed them, without the consent of the people, on the one hand; or without, on the other, a violation of that original contract, which in all states impliedly, and in ours most expressly, subsists between the prince and the subject." 52

Legitimacy offers reasons why a given state deserves the allegiance of its members, but also why the authority of an institution is respected and enforced. Max Weber identified three bases for this authority - traditions and customs; legal-rational procedures (such as voting); and individual charisma. ${ }^{53}$ Some combination of these can be found in most political systems. The first is more relevant with respect to the Crown, but in some respects the others also apply.

In modern democratic societies popular elections confer legitimacy upon governments - though where these processes are disputed legitimacy is threatened. But legitimacy can also be independent of the mere assertion of authority or the opinion of the claimant. This has been particularly important in the late twentieth century discussion of indigenous rights. ${ }^{54}$ Thus rights are not dependent or conditional upon public opinion or majoritarian support indeed, such support is often lacking.

There has been a tendency to undervalue the Crown as a source of legitimacy, because its legitimacy is regarded as of minimal significance compared with that derived from the ballot box. But, in the view of observers such as Smith and Birch, the most important of the defects of the liberal political model of the Westminster-type constitution - the view of the

\footnotetext{
${ }^{52}$ Sir William Blackstone Commentaries on the Laws of England (4 ${ }^{\text {th }}$ edn 1770), Book I, Chapter VII, p 237.

53 See Randall Collins Weberian Sociological Theory (1986).

54 See, for example, Sir Eli Lauterpacht "Sovereignty" (1997) 73(1) International Affairs 137.
} 
political theorist rather than the lawyer or politician - is its failure to depict the role of the Crown in the system of government, and the implications of the interrelated independence of the executive. ${ }^{55}$ The legitimacy of the Crown is dependent on popular support, but is also independent of it.

The legitimacy of the Crown includes that owed to the established regime. With the modern democratic ethos it might be possible to regard legitimacy which has such a basis of authority as weak, but it does nevertheless have its value. In Tuvalu, for instance, respect for the Crown was regarded as instilling a high sense of respect for whoever was occupying the position of GovernorGeneral, not so much because of the incumbent, but rather for the durability of a system which had stood the test of time; the British monarchy. ${ }^{56}$ This was particularly so because the country was linked, by the Crown, with a much larger, world-wide, political entity. In other words, the institution was greater than the individual.

The Crown itself provides some governmental legitimacy, simply because it is a permanent manifestation of authority, a proto-state as some would argue. ${ }^{57}$ Smith has suggested that in Canada the Crown provides the necessary underlying structure for government. This could be true in New Zealand, arguably even more so, since there is no entrenched written constitution upon which constitutional or political thought may focus. ${ }^{58}$ Although electoral support might suffice for much of the legitimacy of government, this is reinforced by the historical continuity of the Crown.

In contrast to a common political theorists' view - which concentrates upon the political actors ${ }^{59}$ - official terminology (the view of the administrator) had in the past tended to emphasise the importance of the Crown. Thus the formal role the Sovereign plays in Parliament conveys a

\footnotetext{
${ }^{55}$ David E Smith The Invisible Crown (1995); Anthony Birch The British System of Government ( $9^{\text {th }}$ edn, 1993).

56 Tauassa Taafahi Governance in the Pacific (1996) p 1.

57 Joseph Jacob The Republican Crown: Lawyers and the Making of the State in Twentieth Century Britain (1996).

58 The Treaty of Waitangi might serve a similar purpose, though it is perhaps unlikely that it would achieve this alone, as opinion polls suggest that it lacks the general support of the non-Maori population; see Paul Perry, and Alan Webster New Zealand Politics at the Turn of the Millennium: Attitudes and Values about Politics and Government (1999) pp 74-75.

${ }^{59}$ Note the emphasis in such works as Jonathan Boston, Stephen Levine, Elizabeth McLeay, Nigel Roberts and Hannah Schmidt "Caretaker Governments and the Evolution of Caretaker Conventions in New Zealand" (1998) 28(4) Victoria University of Wellington Law Review 629, where the institutional role of the Crown is given relatively little coverage.
} 
totally different view to that of the political realist. It is arguably even more inaccurate, as the Sovereign's legislative role has been largely nominal for some three hundred years - except with respect to colonial legislatures, and even here the role has been exercised on the advice of Ministers.

According to Barker, the principal function of the theory of the Crown is to provide a legal person who can act in the courts, to whom public servants may owe and own allegiance, and who may act in all those exercises of authority, such as the making of treaties or the declaration of war, which do not rest upon the legislative supremacy of Parliament. ${ }^{60}$ They are also the legal person who exercises the administrative function of executive government.

In this view, and in the United Kingdom at least, and probably in all the realms also, the legitimacy involved here is quite independent of any popular authorisation, and the idea of the Crown as a legitimising principle is articulated and employed within the personnel and operation of government, though little outside.

Curtailment of the royal prerogative is largely based on its lack of legitimacy, but this is overly simplistic, as the royal prerogative possesses a different type of legitimacy, distinct from the majoritarian dictatorship found in representative parliamentary democracy. It is closer to the legitimacy of the judiciary.

\section{JUSTICIABILITY AND OTHER LIMITATIONS ON THE PREROGATIVE}

Harris, and commentators in the United Kingdom, are concerned with the legitimacy of the royal prerogative, but they are also concerned with the question of the accountability of the executive for its actions. There is a range of ways in which this can be achieved. Each has an important role to play, though for most practical purposes the most effective day-to-day control has proven to be the courts.

It was long maintained that the royal prerogative was generally nonjusticiable (or non-reviewable by the Courts),${ }^{61}$ though it has always been the function of the courts to determine its existence. ${ }^{62}$ The more usual view now is that the justiciability or non-justiciability depends not upon the nature of the

\footnotetext{
${ }^{60}$ Rodney Barker Political Legitimacy and the State (1990) pp 143-4.

${ }^{61}$ For example, see Barton v R (1980) 147 CLR 75, 90 per Gibbs ACJ; Chandler v Director of Public Prosecutions [1964] AC 763; Case of Proclamations (1611) 12 Co Rep 74; 77 ER 1352 (KB).

${ }^{62}$ Council of Civil Service Unions v Minister for the Civil Service [1985] AC 374 per Lord Roskill (obiter) (HL).
} 
power - as part of the royal prerogative - but upon its subject matter. ${ }^{63}$ This has the potential effect of widened the scope of judicial review, though the Courts show deference to those who discharge royal prerogative powers, in the expectation that they will exercise such powers fairly, reasonably, and in accordance with law. ${ }^{64}$

In Gouriet v Union of Post Office Workers, ${ }^{65}$ the House of Lords, while affirming the unreviewability of the Attorney-General's decision to refuse to give his consent to a relator action, emphasised the political nature of the Attorney-General's role rather than its origin in the prerogative. The view seemed to be taking hold that the reviewability of the exercise of powers depended on the nature of the question, and not on the source of the power. The reluctance of the courts to review the prerogative gave ground in the mid1980s, especially in the seminal Council of Civil Service Unions v Minister for the Civil Service ${ }^{66}$ (the GCHQ case). This held that the prerogative power was generally though not universally amenable to review, though the political ones were not. This provided an explanation of the earlier decisions such as Chandler $v$ Director of Public Prosecutions ${ }^{67}$ and Hanratty $v$ Lord Butler of Saffron Walden ${ }^{68}$ which is consistent with the newly stated view. The cases stemming from the depopulation of the Chagos Archipelago ${ }^{69}$ led to the House of Lords deciding, in $R$ (on the application of Bancoult) $v$ Secretary of State for Foreign and Commonwealth Affairs ${ }^{70}$ that the exercise of power by the executive alone was amenable to judicial review.

${ }^{63}$ Ibid; Black v Chretien (2001) 199 DLR (4th) 228 (Court of Appeal of Ontario); Minister for Arts, Heritage \& Environment v Peko-Wallsend Ltd (1987) 15 FCR 274, 277-278 per Bowen CJ, 280 per Sheppard J, 302-304 per Wilcox J; 75 ALR 218 (FC); Macrae v Attorney-General of New South Wales (1987) 9 NSWLR 268, 273, 277, 281 per Kirby P, 308 per Priestley JA (CA); Attorney-General for the United Kingdom v Heinemann Publishers Australia Pty Ltd (1987) 10 NSWLR 86 (CA); Century Metals \& Mining NL $v$ Yeomans (1989) 40 FCR 564, 587-588; 100 ALR 383; 22 ALD 730 (FC); Blyth District Hospital Inc v South Australian Health Commission (1988) 49 SASR 501, 509 per King CJ (FC).

${ }_{64}^{64}$ Burt v Governor-General [1992] 3 NZLR 672, 683 (CA).

${ }^{65}$ [1978] AC 435; [1977] 3 All ER 70 (HL).

${ }^{66}$ Council of Civil Service Unions v Minister for the Civil Service [1985] AC 374 (HL).

${ }^{67}$ [1964] AC 763.

68 [1971] 115 Sol Jo 386; The Times, $12^{\text {th }}$ May 1971 (CA) (prerogative of mercy).

${ }^{69}$ See $R$ (on the application of Bancoult) $v$ Secretary of State for Foreign and Commonwealth Affairs [2008] UKHL 61; [2008] 3 WLR 955 (HL); R (Bancoult) v Secretary of State for Foreign and Commonwealth Affairs (2001) 2 WLR 1219 (HL). 70 [2008] UKHL 61; [2008] 3 WLR 955 (HL). 
Although the courts can now review the exercise of the royal prerogative in certain instances, ${ }^{71}$ as where there is a legitimate expectation, there is no general power of review. ${ }^{72}$ Having said that, in general terms, the exercise of royal prerogative powers is subject to judicial review, although there are exceptions - including the honours prerogative. ${ }^{73}$ These limits have been held to apply particularly to the exercise of what may be termed the political aspects of the royal prerogative. This was important in the context of Black's case. $^{74}$

Limitations on the prerogative as outlined above may potentially undermine both its legitimacy and effectiveness, because it is in danger of being severed from its historic origins. But it may also enhance its legitimacy in other ways, because it involves the addition of new checks and balances. Its effectiveness may also be enhanced, leading us to quite reasonably question why it would need to be abolished, and whether such a step might be counterproductive.

In addition, the curtailment or regulation of the prerogative can cause unexpected problems. This can be seen illustrated, in a quite technical manner, in a recent Irish imbroglio.

\section{THE FATE OF THE PREROGATIVE IN IRELAND}

The abolition of the prerogative - or even its codification - can create problems which may not be anticipated. The experience in Ireland can illustrate this. Once part of the United Kingdom, from the twentieth century Ireland reasserted its ancient independence. But this had certain consequences, some of which were unforeseen, as a result of the way in which independence was achieved, through a series of revolutionary and evolutionary steps, from a once-unitary Crown.

From 1922 the situation became complicated, with the Constitution of the Irish Free State remaining silent on the question of the royal prerogative which was clearly not then transferred to the government of the State, but which probably preserved the royal prerogative in the hands of the King. It seems that the royal prerogative was unaffected by the advent of the Irish Free

${ }^{71}$ Such as when it relates to the honours prerogative; Black $v$ Chretien (2001) 199 $\operatorname{DLR}\left(4^{\text {th }}\right) 228$, paras 27 per Laskin JA (Court of Appeal of Ontario).

${ }^{72}$ Council of Civil Service Unions v Minister for the Civil Service [1985] AC 374 (HL).

${ }^{73}$ As was found in Black $v$ Chretien (2001) 199 DLR $\left(4^{\text {th }}\right) 228$ (Court of Appeal of Ontario).

${ }^{74}$ Ibid. 
State - at least until 1937 (or rather 1936, as shall be seen), and the effective creation of an Irish republic.

The royal prerogative was not transferred or assigned to the Irish government in 1936 or 1937 . From $12^{\text {th }}$ December 1936 the King ceased to be such for all purposes except signing treaties and accrediting envoys, since Irish citizens remained subjects of the Crown. Whilst we must remember that the notion of the separation of the Crowns was not fully developed at this time,$^{75}$ it does show that the transitional period was one in which clear and simple solutions were not always to be obtained.

The question now becomes, what happened to the royal prerogative in Ireland after 1943 (or rather, 1937, which was the year the Constitution of Ireland came into force, or 1936, when the Executive Authority (External Relations) Act 1936 replaced the King as Sovereign, and retaining the King as an organ - only for certain limited external purposes) $?^{76}$

It has been claimed that State inherited the royal prerogative. Unfortunately this does not seem to be correct. In the case of Byrne $v$ Ireland $^{77}$ the Supreme Court of Ireland categorically established that the Irish Republic did not inherit the royal prerogative. ${ }^{78}$ It was apparently excluded indeed this occurred in $1922,{ }^{79}$ rather than in 1937, or in 1949, when Ireland became officially as well as effectively a republic.

Had the royal prerogative been included in the 1922 constitution, or subsequently assigned to the Irish State, it would have transferred to the new one in 1937; however it is not clear that it was included. No express provision was made for royal prerogatives in the 1922 Constitution. ${ }^{80}$ Certain royal prerogatives continued to be exercised by the King until 1936. The royal prerogatives were left with the King after 1922, and not incorporated into the Constitution.

The Executive Authority (External Relations) Act 1936 restricted the powers of the Crown to signature of treaties and accreditation of envoys. The Act itself did more than restrict the powers of the Crown. In an adroitly

\footnotetext{
75 Generally, see Noel Cox "The control of advice to the Crown and the development of executive independence in New Zealand” (2001) 13(1) Bond Law Review 166.

${ }^{76}$ Constitution (Amendment No 27) Act 1936 (Eire).

77 [1972] IR 241 (Sup Ct (Irl)).

78 Supported by Webb v Ireland [1988] IR 353 and Geoghegan v Institute of Chartered Accountants [1995] 3 IR 86.

${ }^{79}$ The Constitution of Saorstát Éireann 1922.

${ }^{80}$ Kevin Costello "The Expulsion of Prerogative Doctrine from Irish Law: Quantifying and Remedying the Loss of the Royal Prerogatives" (1997) 32 Irish Jurist 145 at 164 .
} 
worded section, ${ }^{81}$ it was provided that, from the passage of the Act $\left(12^{\text {th }}\right.$ December 1936), the King "cease[d] to be King" for "all other (if any) purposes", except for those of s 3(1). The King for the purposes of s 3(1) would be the person who would be his successor under the law of the Irish State - the Act provided for the abdication of King Edward VIII. Section 3(1) does not make the 'King' King of Ireland, but rather provides that the King of Australia, Canada, Great Britain, New Zealand, and South Africa, had certain limited and defined responsibilities with respect to Irish foreign relations.

On December $29^{\text {th }} 1937$ a new Constitution entered into force, which was republican in form, if not in name. It made no mention of the King as Sovereign, who had effectively been removed as of the precious December by the Executive Authority (External Relations) Act 1936. This Act continued in force. The King as Sovereign was no longer the head of the Irish executive, but merely an organ or instrument, authorised by the Government of Ireland, to play a specific role in external affairs.

Article 49 of the new Constitution provided for the transmission of the powers, functions, rights and prerogatives held by the Irish State before $11^{\text {th }}$ December $1936,{ }^{82}$ to the Oireachtas. The crucial elements to note are that the powers that were transferred under Article 49 were those held by the State at that time, and that these powers were transferred to the legislature, not the executive.

Although the Executive Authority (External Relations) Act 1936 had effectively excised the King as of the $12^{\text {th }}$ December 1936, the new Constitution preserved all 'prerogatives' held by the Irish State as of the previous day. The question then becomes this: were the royal prerogatives of the King held by the Irish State on $10^{\text {th }}$ December 1936? If they were, then they were inherited, under the 1937 Constitution, by the Oireachtas. If they were held by the King, as distinct from the State - if that distinction could be made - then they were not inherited.

It would be usual to assume that the powers of the King would be counted among the powers of the state. In the 1922 Constitution the King was envisaged as being part of the state. ${ }^{83}$ Article 2 stated that "All powers of

${ }^{81}$ Executive Authority (External Relations) Act 1936 (Ireland), s 3(2).

${ }^{82}$ The Executive Authority (External Relations) Act 1936 (Ireland) provided that Edward VIII remained king in the Irish Free State until $12^{\text {th }}$ December 1936. The effect of Article 49(1) was that none of the royal prerogatives held by King George VI were transferred. There is also an argument in Ireland that since the Irish Free State had not been consulted as to the abdication of Edward VIII he remained king of Ireland until the office was abolished.

${ }^{83}$ Though he was, in the 1922 Constitution, part of Parliament: "All powers of government and all authority, legislative, executive, and judicial, in Ireland are 
government and all authority, legislative, executive, and judicial, in Ireland are derived from the people of Ireland, and the same shall be exercised in the Irish Free State (Saorstát Eireann) through the organisations established by or under, and in accord with, this Constitution". Article 51 provided that "The Executive Authority of the Irish Free State (Saorstát Eireann) is hereby declared to be vested in the King, and shall be exercisable, in accordance with the law, practice and constitutional usage governing the exercise of the Executive Authority in the case of the Dominion of Canada, by the Representative of the Crown." Together these would appear to suggest that the royal prerogative - which is probably not mentioned in the Constitution because it is regarded as being a distinct type of law - would be a 'prerogative of the state'.

The 1937 Constitution stated that "the powers, functions, rights and prerogatives held by the Irish State" before $11^{\text {th }}$ December 1936 were inherited by the new Constitution. Articles 12 and 51 of the 1922 Constitution could be interpreted as embracing the royal prerogative as part of the powers, not of the Constitution per se, but of the King as the person in whom was vested the Executive Authority of the Irish Free State. However, in 1922 the concept of the division of the Crown was not well developed, and it is likely that the royal prerogative was not intended to be patriated in this manner. Indeed, it would seem that the British Government was opposed to a transfer of the office to the control of the Irish Free State because of the concern that this would harm the unity of the Crown and the royal prerogative. This attitude could only be maintained if the royal prerogative is seen as being distinct from the 'executive authority' of the 1922 Constitution.

Thus it is not clear whether the royal prerogative was a 'prerogative held by the Irish State', and therefore inherited by that State in 1937. Although it might be a conceptually stronger argument to assert that the royal prerogative was included in the 1922 Constitution, we are bound by the decisions in Byrne $v$ Ireland, ${ }^{84}$ and subsequent cases, that the royal prerogative was not transferred to the Irish State.

The safest conclusion is that the royal prerogative was not transferred to the Irish Government in 1922, or subsequently prior to $11^{\text {th }}$ December 1936. This illustrates the dangers of ignoring the royal prerogative, because of its

derived from the people of Ireland, and the same shall be exercised in the Irish Free State (Saorstát Eireann) through the organisations established by or under, and in accord with, this Constitution" (Article 12).

${ }^{84}$ [1972] IR 241 (Sup Ct (Irl)). 
comparatively narrow scope, or even of simply abolishing it - the very uncertainty of the prerogative is both a curse and a blessing. ${ }^{85}$

The Irish experience may be compared and contrasted with that elsewhere. It would, in principle, be easy to simply enact that the executive powers of the state are vested in the Sovereign - or the President, in the case of a republic. This is actually done in most realms. For example, the Belize Act 1981, the schedule of which contains the Constitution of Belize, simply provides that:

"The executive authority of Belize is vested in HM." $" 86$

Similarly s 61 of the Commonwealth of Australia Constitution Act $1900^{87}$ provides that:

"The executive power of the Commonwealth is vested in the Queen and is exercisable by the Governor-General as the Queen's representative, and extends to the execution and maintenance of the laws of the Commonwealth."

However, the constitutional provision alone isn't a satisfactory basis for executive authority, and in all these latter instances the royal prerogative remains. This has proven to be of benefit, as in Tuvalu, where the Governor General was held to have had discretion to act in "his own, deliberate judgement", despite the stricter wording of the Constitution. ${ }^{88}$ Abolition of the royal prerogative presents some difficulties, both in codifying the law, and also in determining precisely what should be covered. Codification, by its very nature, presupposes that it is possible to provide a precise list of the required powers of the executive.

\section{CONCLUSION}

The replacement of the royal prerogative with statutory authority, whether piecemeal or in its entirety, may be justified on that grounds that this would allow greater parliamentary control of the executive. Whilst this might appear logical from the viewpoint of providing a democratic mandate for

\footnotetext{
${ }^{85}$ This latter is seen most clearly in the national security cases, which rely heavily on the malleability of the prerogative.

${ }^{86} \mathrm{~S} 36(1)$.

${ }^{87} 63$ \& 64 Vict c 12 (UK).

${ }^{88}$ Amasone v Attorney General (2003) TVHC 4 (Tuvalu); Constitution of Tuvalu (1978). See also Billy Hilly $v$ the Governor-General of the Solomon Islands [1994] SBCA 1 (CA of Solomon Islands).
} 
governmental action, it risks making a significant change to the constitutional balance. Ministerial responsibility already allows Parliament to exercise a considerable degree of control over the executive, including the use of the royal prerogative. But the principle of separation of powers surely requires that the executive ought to be free, at least to some degree, to exercise its proper functions without undue interference from the other branches of government. Already the royal prerogative is largely subject to judicial review (for instance, in $R$ (on the application of Bancoult) $v$ Secretary of State for Foreign and Commonwealth Affairs ${ }^{89}$ [the House of Lords saw "no reason why prerogative legislation should not be subject to review on ordinary principles of legality, rationality and procedural impropriety in the same way as any other executive action"]), and it is only exercised - with rare exceptions - on the advice of Ministers responsible to Parliament. Arguably the independence of the royal prerogative from parliamentary control is its strength, not a weakness.

Perhaps more fundamentally, the royal prerogative already offers a system of legal powers, immunities and privileges with their own legitimacy and authority, well developed, flexible and venerable. While some reforms may be appropriate, in general the royal prerogative is too valuable to be lost, or seriously weakened, merely to confer greater control by majoritarian parliamentarians over the executive. Reliance on judicial review of the royal prerogative (and its preservation) ensures that there are greater checks and balances in the constitution, especially in the United Kingdom, with the advent of the new Supreme Court, and in the absence of a written constitution.

${ }^{89}$ [2008] UKHL 61; [2008] 3 WLR 955. 